
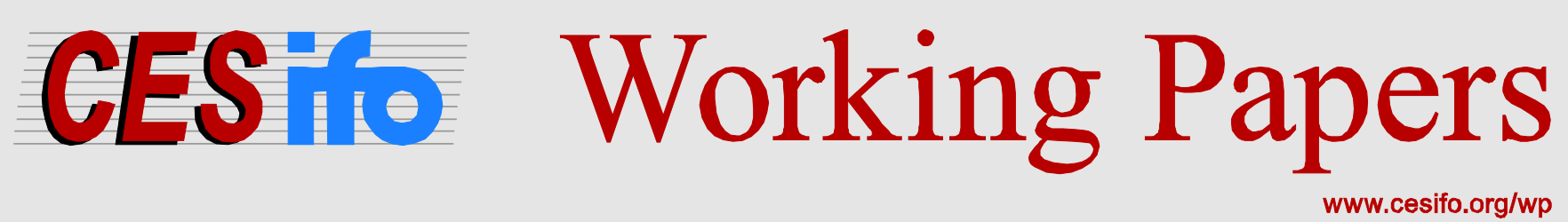

\title{
The Lasting Effects of Maternal Net Nutrition during US Economic Development
}

\author{
Scott Alan Carson
}

CESIFO WORKING PAPER NO. 5827

CATEGORY 4: LABOUR MARKETS

MARCH 2016

An electronic version of the paper may be downloaded

- from the SSRN website: Www.SSRN.com

- from the RePEc website: Www.RePEc.org

- from the CESifo website: www.CESifo-group.org/wp 


\title{
The Lasting Effects of Maternal Net Nutrition during US Economic Development
}

\begin{abstract}
When traditional measures for economic welfare are scarce or unreliable, stature and the body mass index (BMI) are now widely-accepted measures that reflect economic conditions. However, little work exists for late 19th and early 20th century women's BMIs in the US and how they varied with economic development. This study shows that after controlling for characteristics, African-American women had greater BMIs than lighter complexioned black and white women. Women from the Southwest were taller and had lower BMIs than women born elsewhere within the US. However, women's BMIs did not vary by occupations. Women's BMIs decreased throughout the late 19th and early 20th centuries, which may have implications for the health and cognitive development of lower socioeconomic status children who reached maturity in the mid-20th century.
\end{abstract}

JEL-Codes: N310, N320, I120, J150.

Keywords: late $19^{\text {th }}$ and early $20^{\text {th }}$ century women's BMIs, ethnicity and BMI, women's health during economic development.

Scott Alan Carson

University of Texas, Permian Basin

4901 East University

USA - Odessa, TX 79762

Carson_S@utpb.edu

I appreciate comments from John Komlos, Rick Steckel, Doug Henderson, Shahil Sharma, Chinuedu Akah, Meekam Okeke, Lee Carson, Joe Beene, and Paul Hodges. 


\section{Introduction}

The health and nutrition of late $19^{\text {th }}$ and early $20^{\text {th }}$ century women in the US offers insight into economic conditions and health during development. Two commonly used measures for health and net nutrition are stature and the body mass index (BMI). Average stature measures the cumulative net difference between calories consumed and calories required for work and to withstand the physical environment. Sunder (2011), Carson (2011), and Carson (2013) demonstrate that US women's average statures were roughly constant throughout the antebellum period but increased during the second half of the $19^{\text {th }}$ century. The body mass index measures current net nutrition (Komlos, 1987; Fogel, 1994, pp. 157-158), ${ }^{1}$ and while important progress has been made in understanding late $19^{\text {th }}$ and early $20^{\text {th }}$ century male BMI variation, little is known about how black and white women’s BMIs varied with US economic development (Carson, 2009; Carson, 2012). Moreover, women’s BMI variation not only reflects their current net nutrition but the health, cognitive development, and future labor market productivity of their off-spring (Sørensen et al, 1997, p. 402; Risnes et al. 2011; Case and Paxson, 2008a; Carson and Paxson, 2008b).

\footnotetext{
${ }^{1}$ Interpreting BMI variation is more complicated than evaluating stature variation because BMI is the ratio of weight in kilograms divided by height in meters squared. Interpreting BMI variation is also more difficult than interpreting stature variation because BMI variation depends on when privation occurs. For example, if an individual receives insufficient calories nutrition in their youth, they are less likely to reach their genetically predetermined stature, and their BMIs will be high if they receive excess calories as an adult because greater weight is distributed over smaller physical dimensions (Herbert et al.. 1993, p. 1438; Sorkin et al., 1999; Sorkin et al., Sorkin et al., 1999).
} 
In both historic and modern populations, BMI variation reflects multiple health conditions, and individuals with low BMIs are more likely to have poor net nutrition throughout life and experience infectious and respiratory diseases (Calle et al. 1999, p. 1001; Jee et al. 2006, p. 783). Individuals with high BMIs are at greater risk for all-source morbidities and mortalities (Waaler, 1984; Koch, 2011; Meyer et al. 2003), and obese individuals are more likely to develop diabetes, cardiovascular disease, and stroke (Monson et al. 1990; Monson et al. 1991; Herbert et al. 1993; Must et al. 1999). For overweight and obese individuals, health studies also demonstrate that there are significant benefits associated with weight loss (Wing and Phelan, 2005) and weight loss is most beneficial if it occurs over prolonged periods (Guth, 2014).

Women are more likely to be obese then men, and multiple explanations account for the difference (Must and Evans, 2011; Ogden et al.2006; Flegal et al. 2010). For example, the distribution of women's fat may have played an evolutionary role in their sexual attractiveness and reproductive success (Dunbar, 2013, p. 56; Symons, 1995; Tovée et al. 1998, p. 548), and women need more stored calories to fuel the development of large-brain offspring (Dunbar, 2013, p. 55). During pregnancy, women are more likely to put on excess weight that can be difficult to lose after child-birth (Leiberman, 2000, p. 1064). Obesity is inversely related with stature, and women reach shorter statures than men (Sorkin et al. 1999a; Brownson, Boehmer, and Luke, 2005, p. 425; Herbert et al. 1993, p. 1438). There is also the psycho-social relationship between gender and obesity, and women are more likely than men to be depressed and obese (Rosmund and Bjürnturp, 1999; Granberg, 2011, p. 330; Belue, Francis, and Calaco, 2009; Ge, Elder, Regnerus, and Cox, 2001; Needham and Crosnoe, 2005). There is also an intergenerational effect, where a mother's weight status is related to the cognitive development and later-life health of her off-spring (Risnes et al. 2011). Furthermore, failure to put on sufficient 
weight during pregnancy has detrimental health consequences for her off-spring, and underweight women are more likely to experience pre-term labor and delivery, give birth to low birth-weight babies, experience maternal fever, encounter perinatal complications, and experience fetal growth restriction (Doherity, et al., 2006; Abrams et al, 2000; Yan, 2015; Rode et al. 2007; Ehrenberg et al. 2003, pp. 1728-1729). For pregnant women, failure to gain weight during pregnancy may impede the cognitive development to her off-spring (Abrams et al. 2000; Sørensen et al, 1997, p. 402).

Nevertheless, wide-spread obesity is a recent phenomenon and was not common until the mid-20 ${ }^{\text {th }}$ century (Carson, 2009a; Komlos and Brabec, 2010; Carson, 2012a). To better understand the modern obesity epidemic, observing women's BMI variation before modern economic conditions transitioned to the modern diet with less physical activity levels sheds light on how female BMIs have changed over time. Furthermore, an unanswered question in health studies is how women's $19^{\text {th }}$ century BMIs varied over time, with economic development, and how this may have been related to their off-spring's current and future health (Barker, 1992; Osmania and Sen, 2003; Risnes et al, 2011). Given US family calorie priorities, historical labor market segregation meant that more calories were devoted to men, who did a greater share of field work and consumed a longer share of calories within the household. Women's net nutritional needs during economic development may have, therefore, been queued behind men because men had greater physical strength and required more calories within the household (Osmani and Sen, 2003; Burnette, 2013, p. 306).

It is against this backdrop that this study considers three paths of inquiry into late $19^{\text {th }}$ and early $20^{\text {th }}$ century US female BMI variation. First, how were women's BMIs distributed historically by race, and were black women's BMIs greater than white women? After 
controlling for characteristics, darker complexioned black women had greater BMIs than fairer complexioned mixed-race women, which were, in turn, greater than white women. Second, how did black and white women’s BMIs vary overtime? Between 1860 and 1930, black women’s BMIs decreased by 14 percent, while white women’s BMIs decreased by nearly 17 percent. Third, how did women's BMIs vary by residence? Women from the Southwest had lower BMIs than women located elsewhere within the US, while women from the Northeast and Europe had higher BMIs.

\section{Late $19^{\text {th }}$ and Early $20^{\text {th }}$ Century Women's BMI Data}

Locating data to evaluate late $19^{\text {th }}$ and early $20^{\text {th }}$ century women's BMIs and heights is more difficult than locating data for men because women did not participate in activities and institutions that recorded weight and height, such as the military. An alternative source for weight and height data is prisons; however, women were also less likely than men to commit and be incarcerated for criminal activity, which further limits the data available to evaluate their BMIs (Steffensmeier and Allan, 1996). ${ }^{2}$ This study uses late $19^{\text {th }}$ and early $20^{\text {th }}$ century US prison data to analyze women’s BMI variation during US economic development. While additional weight and height data for women's health are yet to emerge, prison data are the only source that currently exists that contains a sufficient number of observations to meaningfully consider their historical BMI variation.

Data to observe late $19^{\text {th }}$ and early $20^{\text {th }}$ century women's BMIs is part of a large prison data extraction project. All US prisons were contacted on multiple occasions and available records were combined into a large data set. Between 1866 and 1939, women’s physical

\footnotetext{
${ }^{2}$ For both women and men, there were fewer $19^{\text {th }}$ century weight recordings then statures (Carson, 2011; Carson, 2013).
} 
descriptions were recorded by prison enumerators at the time of incarceration, therefore, reflects pre-incarceration conditions. Prison officials recorded inmates' gender, prison entry date, complexion, nativity, occupations, residence, and age. In this pre-photographic period, enumerators were careful when recording physical descriptions because accurate records had legal implications for inmate identification in case they escaped and were recaptured. Physical descriptions also helped identify individuals within prisons. There are 4,766 women in the data set used here. From the same prisons, there are 205,456 male inmates with weight and height data, indicating that women made up about 2.3 percent of the prison population; however, the ratio of female to male prisoners varied across prisons. For example, women were over four percent of the Colorado and Illinois state prison populations but less than .5 percent of the Oregon and Washington state prison populations.

While valuable, data from prison weight and height records are not above scrutiny. For example, law enforcement may have varied with economic and political conditions. Prison data may reflect shorter individuals who received sub-standard diets throughout their growth years and reflects poor health; therefore, women in prison may reflect conditions among poorer, lower socioeconomic status women who turned to crime for survival (Bodenhorn, Moehling, and Price, 2012). Another concern is ethnic status, where law enforcement officials and courts selectively enforced legal statutes against $19^{\text {th }}$ century black women and other ethnic groups relative to white women. However, there is little evidence from the prison records that physical sizes were systematically targeted for incarceration. In comparison, male prison stature and BMI variation are similar to non-prison samples, indicating that prison records are a valuable source for lower socioeconomic status women relative to the general population (Komlos, 1987; Margo and 
Steckel, 1992). ${ }^{3}$ Consequently, caution is taken when evaluating female prison records; however, to date, prison records have the greatest potential to examine late $19^{\text {th }}$ and early $20^{\text {th }}$ century lower socio-economic status women’s BMIs and stature variation over time and across characteristics.

Complexion was an important means to identify individuals within prisons, and enumerators recorded inmate complexions in detail. Women of African descent were recorded as black, light black, dark black, and diverse shades of 'mulatto'. Women of European descent were recorded as fair, light, medium, and dark. Both in the US population census and US prisons, women of mixed African and European descent were classified as 'mulattos' but are referred to in this study as 'mixed race' (Bodenhorn, 2015, p. 5). ${ }^{4}$ While women with mixed race complexions shared genetic traits from both African and European origin, they were treated with lower social and economic priority during the $19^{\text {th }}$ century and are grouped here with black women. Mixed race complexions were defined as quadroon, who is a person with one-quarter African ancestry, and octoroon, who is a person with one-eighth African ancestry. However, parsing mixed-complexions beyond this is neither possible nor accurate. Other complexions used in the prison records for women are Native-American and Mexican.

\footnotetext{
${ }^{3}$ Floud et al. (2011, p. 331) present estimates for $19^{\text {th }}$ century US males. Their male stature estimates are only .5 percent taller than male prison stature estimates.

${ }^{4}$ Through the 1930 United States population census, the term 'mulatto' was how person's of European and African descent were referenced.
} 
Table 1. Black and White Female Demographics, Residence, and Occupations

\begin{tabular}{|c|c|c|c|c|c|}
\hline Nativity & $\mathbf{N}$ & Percent & Prison & $\mathbf{N}$ & Percent \\
\hline Northeastern & 19 & .40 & Arizona & 26 & .55 \\
\hline Middle & 563 & 11.81 & Colorado & 308 & 6.46 \\
\hline Atlantic & & & & & \\
\hline Great Lakes & 407 & 8.54 & Idaho & 12 & .25 \\
\hline Plains & 536 & 11.25 & Illinois & 510 & 10.70 \\
\hline Southeast & 1,711 & 35.90 & Kentucky & 124 & 2.60 \\
\hline Southwest & 925 & 19.41 & Mississippi & 49 & 1.03 \\
\hline Far West & 91 & 1.91 & Missouri & 496 & 10.41 \\
\hline Foreign Born & & & Montana & 86 & 1.80 \\
\hline British & 186 & 3.90 & Nebraska & 113 & 2.37 \\
\hline Canada & 34 & .71 & New Mexico & 56 & 1.17 \\
\hline Europe & 150 & 3.15 & Oregon & 3 & .06 \\
\hline $\begin{array}{l}\text { Latin } \\
\text { America }\end{array}$ & 85 & 1.78 & $\begin{array}{l}\text { Pennsylvania, } \\
\text { East }\end{array}$ & 218 & 4.57 \\
\hline Unknown & 59 & 1.24 & $\begin{array}{l}\text { Pennsylvania, } \\
\text { West }\end{array}$ & 184 & 3.86 \\
\hline Ages & & & Philadelphia & 377 & 7.91 \\
\hline Teens & 1,094 & 22.95 & Tennessee & 1,055 & 22.14 \\
\hline Twenties & 2,231 & 46.81 & Texas & 1,087 & 22.81 \\
\hline Thirties & 911 & 19.11 & Utah & 59 & 1.24 \\
\hline Forties & 354 & 7.43 & Washington & 3 & .06 \\
\hline Fifties & 126 & 2.64 & Occupation & & \\
\hline Sixties & 43 & .90 & Skilled & 433 & 9.09 \\
\hline Seventies & 7 & .15 & Unskilled & 583 & 12.23 \\
\hline Birth Decade & & & Domestic & 2,481 & 52.06 \\
\hline $1810 \mathrm{~s}$ & 11 & .23 & $\begin{array}{l}\text { No } \\
\text { Occupations }\end{array}$ & 1,269 & 26.63 \\
\hline 1820s & 40 & .84 & $\begin{array}{l}\text { Decade } \\
\text { Received }\end{array}$ & & \\
\hline 1830s & 103 & 2.16 & 1860s & 20 & .42 \\
\hline 1840s & 253 & 5.31 & 1870s & 318 & 6.67 \\
\hline 1850s & 472 & 9.90 & 1880s & 896 & 18.80 \\
\hline 1860s & 822 & 17.25 & 1890s & 868 & 18.21 \\
\hline 1870s & 1,222 & 25.64 & 1900s & 1.323 & 27.76 \\
\hline 1880s & 1,144 & 24.00 & 1910s & 1,064 & 22.32 \\
\hline 1890s & 582 & 12.21 & 1920s & 252 & 5.29 \\
\hline 1900s & 117 & 2.45 & 1930s & 25 & .52 \\
\hline Ethnicity & & & & & \\
\hline Native & 5 & . 10 & & & \\
\hline American & & & & & \\
\hline Black & 1,786 & 37.47 & & & \\
\hline Mixed-Race & 1,144 & 24.00 & & & \\
\hline Mexican & 86 & 1.80 & & & \\
\hline
\end{tabular}




\begin{tabular}{l|cc}
\hline White & 1,660 & 34.83 \\
Unknown & 85 & 1.78 \\
Complexion & & \\
\hline
\end{tabular}

Source: Arizona State Library, Archives and Public Records, 1700 W. Washington, Phoenix, AZ 85007; Kentucky Department for Libraries and Archives, 300 Coffee Tree Road, Frankfort, KY 40602; Missouri State Archives, 600 West Main Street, Jefferson City, MO 65102; William F. Winter Archives and History Building, 200 North St., Jackson, MS 39201; New Mexico State Records and Archives, 1205 Camino Carlos Rey, Santa Fe, NM 87507; Tennessee State Library and Archives, $4037^{\text {th }}$ Avenue North, Nashville, TN 37243 and Texas State Library and Archives Commission, 1201 Brazos St., Austin TX 78701.

Enumerators recorded a broad set of occupations and defined them narrowly, and enumerators used over 200 occupations to classify pre-incarceration occupations. Women's occupations are classified here into four categories. The most prominent $19^{\text {th }}$ century occupation for women was domestic laborer, such as cooks and household laborers. Women were also in low skilled occupations, such as waitresses and laborers. Women found limited access into skilled occupations, such as dressmakers and nurses; however, late $19^{\text {th }}$ and early $20^{\text {th }}$ century women's skilled occupations were those that served other women (Golden, 1990; Burnette, 2013, pp. 306-307). A final occupation is used for women who reported no occupation to prison enumerators. Subsequently, women within US prisons likely represented lower socioeconomic groups, but there is occupational and regional representation within the sample.

Most women in the sample were born in the South; however, there were sizeable portions from Middle Atlantic, Plains, and Great Lake states (Table 1). The largest cohort of women's international nativity was from the United Kingdom and Continental Europe (Cohn, 2009). Latin American and Canadian women are also in the sample but made-up smaller proportions. 
Crime is committed by younger individuals, and women in their teens and twenties made up the largest share of the $19^{\text {th }}$ century US prison population (Hirschi and Gottfredson, 1983; Carson, 2009b). The complexion of most women in the sample was of African ancestry, and disproportionate representation for women of African descent may indicate selective law enforcement and incarceration because of social processes that disproportionately targeted black women. Alternatively, disproportionate representation for women of African descent may be the result of women having less income and wealth, which made them more likely to commit crime and be incarcerated. Black women also had less income and wealth, which made them more likely to work outside the home than white women, which put then into environments where crime was more likely (Sunstrum, 2013, p. 332; Bodenhorn, 2015, pp. 144-166). Lower income and wealth also meant black women were less able to afford legal counsel at trial (Walker, 1988). By residence, most women were from Tennessee and Texas, but there were also women from further north in Illinois and Pennsylvania. One half of women’s occupations were in domestic labor. Most women in the sample were born between the 1870s and 1880s, and incarcerated between 1900 and 1920.

There are various ways to classify weight status, and BMI has emerged as the primary means of to classify weight across modern and historical populations. Individuals with BMIs greater than 29.9 are classified as obese. Individuals with BMIs between 29.9 and 24.9 are overweight; individuals with BMIs between 24.9 and 18.5 are normal; individuals with BMIs less than 18.5 are underweight. While BMIs allow for easy weight classification, there are various short-comings when using BMIs to classify weight status (Burkhauser and Cawley, 2008). For example, BMIs does not distinguish between fat and fat-free mass, which means that muscular individuals and African-Americans are more likely to be classified as obese when, in 
fact, their weight is appropriate for their height and fat-free composition. Nevertheless, weight classification using BMIs is useful in both modern and historic populations and reflects health conditions in the late $19^{\text {th }}$ and early $20^{\text {th }}$ centuries (Zimmerman et al. 2004; WHO, 1985; Garrow and Webster, 1985).

Figure 1, Late $19^{\text {th }}$ and Early $20^{\text {th }}$ Century Women's BMI Classifications

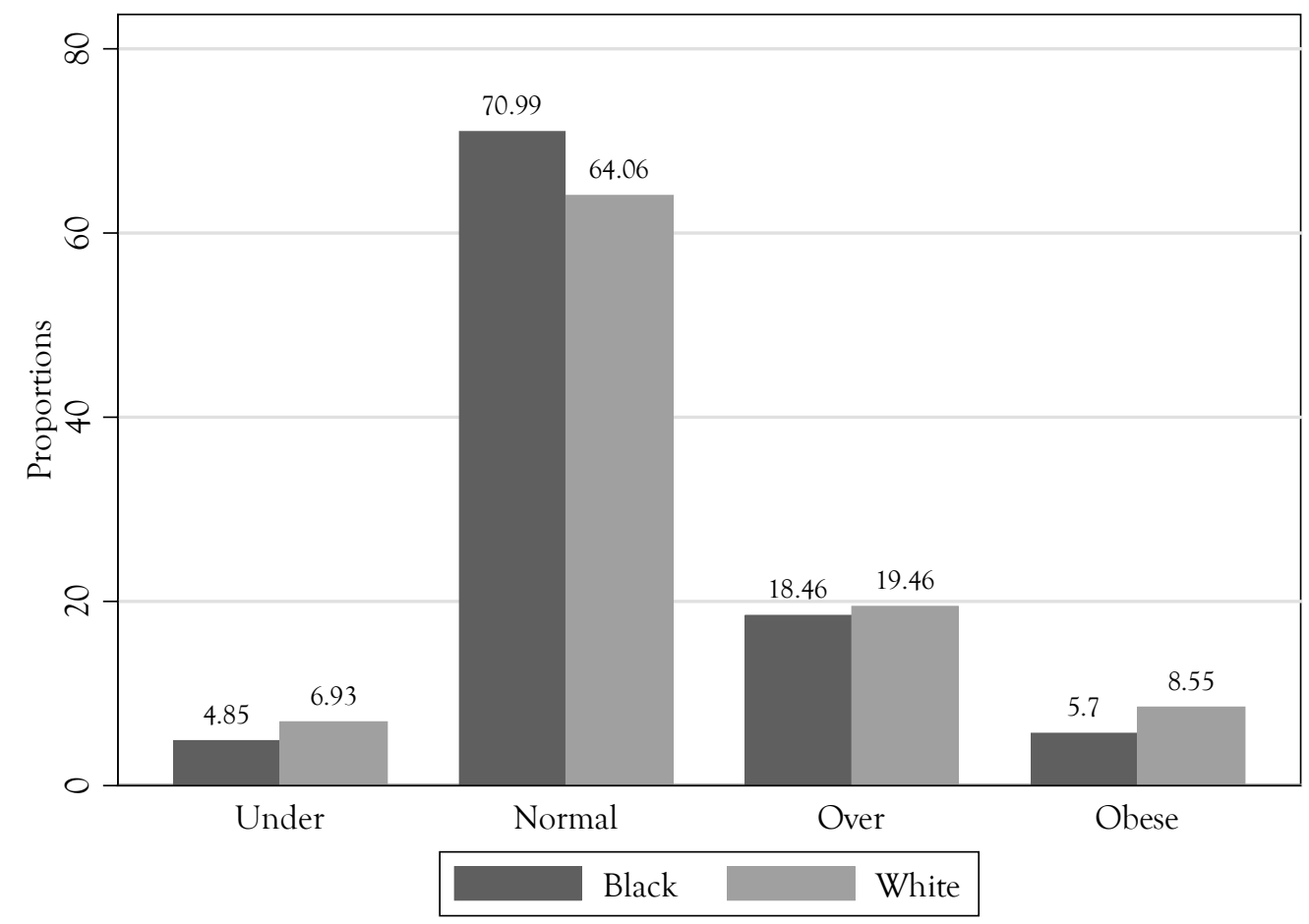

Source: See Table 1.

How BMIs are distributed indicates much about a population’s net nutrition, and given similar means, if the distribution is positively skewed, there is a disproportionate number of underweight individuals. If the distribution is negatively skewed, there is a disproportionate number of overweight and obese individuals. Early British and European male workers did not 
receive sufficient net calories per day to accumulate excess weight relative to calories expended and likely had low BMIs (Fogel, 1994, p. 372; Fogel, 2004, p. 9). However, late $19^{\text {th }}$ and early $20^{\text {th }}$ century US male BMIs were in normal categories (Carson, 2009; Carson, 2012).

Figure 2, Late $19^{\text {th }}$ and Early $20^{\text {th }}$ Century Women's BMIs
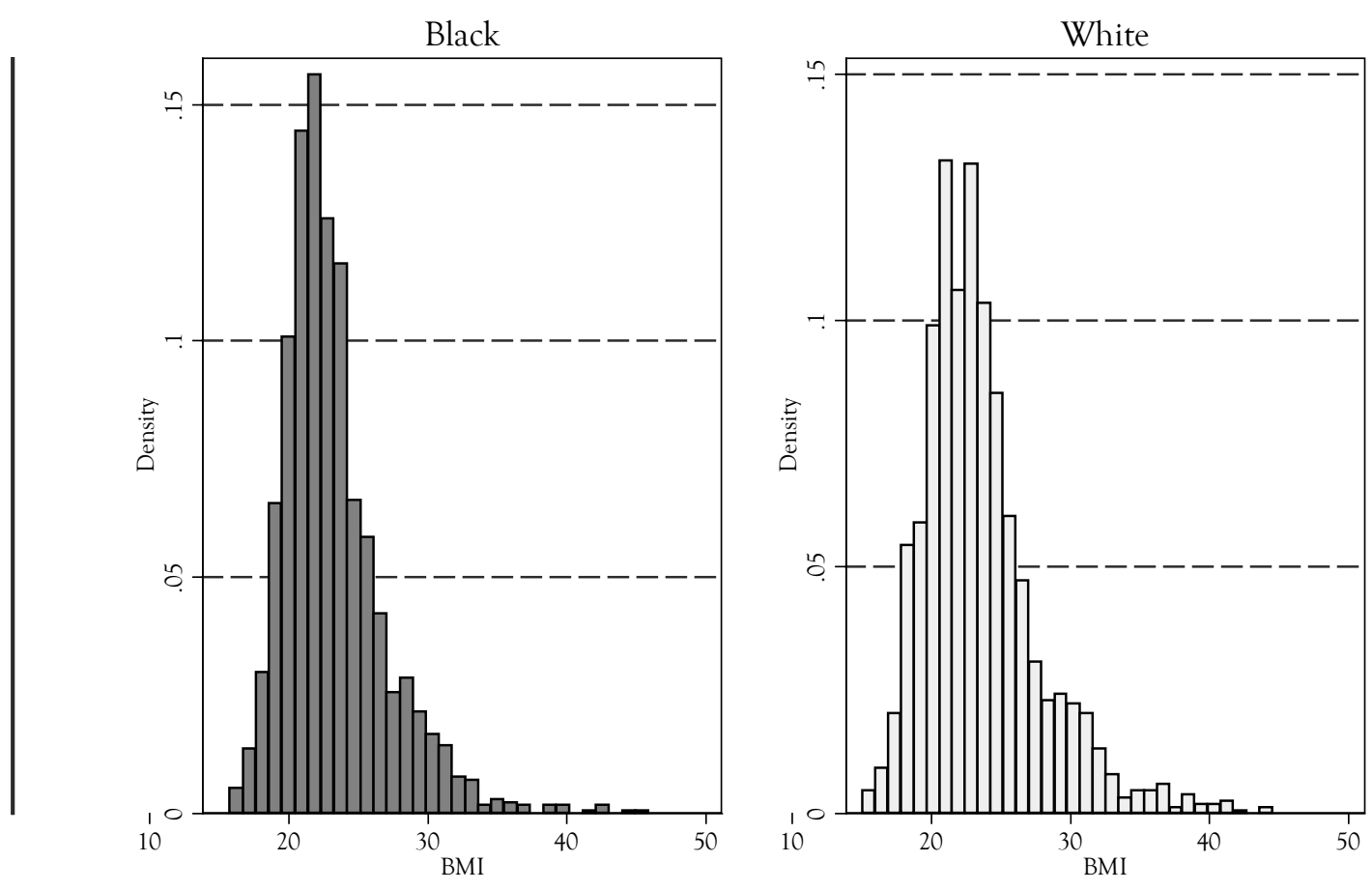

Source: See Table 1. 
Women’s BMI distributions reflect their current health and the health of their off-spring. Modern research in women's health indicates that underweight women give birth to children with low birth weights that have short gestation periods (Abrams et al., 2000, p. 1235s and 1240s). Late $19^{\text {th }}$ and early $20^{\text {th }}$ century women's BMIs were in the normal category (Figure 1 ), and the percent of women in the underweight category was surprisingly low (Figure 2). Only 4.85 percent of black women and 6.93 percent of white women were in the underweight category, and white women were 42.89 percent more likely to be underweight compared to black women. Nearly 71 percent of black women and 65 percent of white women were in the normal BMI category. Around 19 percent of black women and 20 percent of white women were overweight, while 5.8 percent of black women and 8.6 percent of white women were obese.

In the late $19^{\text {th }}$ and early $20^{\text {th }}$ centuries, black and white women were fecund between the ages of 15 and 42 (Steckel, 1986b, p. 451), and the average fecund black women’s BMI was 23.13 with 4.46 percent underweight. The average white fecund women’s BMI was 23.29 with 6.70 percent underweight. To the extent that mother’s average BMI and weight classification represent in-utero conditions, average white women's BMIs were greater but there was a greater share of white women in the underweight category, indicating that lower socioeconomic status white women were more likely to have low birth weight babies that were small for gestation compared to historical black women. Nineteenth century women’s BMIs also reflect the neonatal conditions of their off-spring. During slavery, black children had greater mortality rates than other children within the US, which indicates that in-utero black conditions for underweight black mothers may be the reason for high black childhood mortality rates (Steckel, 1986, p. 727). That late $19^{\text {th }}$ and early $20^{\text {th }}$ century white women in lower socioeconomic statuses were more 
likely to be underweight than black women indicates disproportionately high slave and black child mortality rates were likely due to conditions after birth than in-utero conditions. (Steckel, 1986b, pp. 450-453). Women who are overweight and obese are more likely to experience adverse reproductive health complications compared to women in normal BMI categories (Siega-Riz, Siega-Riz, and Laraia, 2006). Morbid obesity is defined as a BMI greater than 40, and only .28 percent of black women, and .78 percent of white women were morbidly obese. This compares to modern samples, where 17.70 percent of black women and 19.12 percent of white women are morbidly obese, indicating that late $19^{\text {th }}$ and early $20^{\text {th }}$ century women were unlikely to give birth to obese children and experience health consequences associated with obesity.

\section{Women's BMIs by Socioeconomic Status, Residence, and Observation Period}

BMI distributions reflect whether a population is underweight or obese. They do not, however, indicate how BMIs varied over time and with characteristics. To start, BMIs are assumed to be related to height, age, complexion, nativity, residence, occupation, and decade of measurement. Ordinary least squares is used to assess how women's BMIs varied with characteristics. Multinomial obesity regression models are used to assess the relative risk of being in a given BMI category relative to the normal category.

$$
\begin{gathered}
\ln \left(\frac{p_{j}}{p_{\text {Normal }}}\right)=\theta_{0}+\theta_{H} \text { Centimeter }_{i}+\sum_{a=\text { Preteen }_{a}}^{70 s} \theta_{a} \text { Ages }_{i}+\sum_{c=1}^{5} \theta_{c} \text { Complexion }_{i}+\sum_{n=1}^{11} \theta_{n} \text { Nativity }_{i} \\
+\sum_{p=1}^{16} \theta_{p}{\text { Re } \text { sidence }_{i}}+\sum_{l=1}^{3} \theta_{l} \text { Occupation }_{i}+\sum_{t=1860 \mathrm{~s}}^{1930 s} \theta_{t} \text { Observation Decade }_{i}+\varepsilon_{i}
\end{gathered}
$$

Stature in centimeters is included to account for the inverse relationship between BMIs and height. To account for how women’s BMIs increased with age, annual youth dummy 
variables are included for women’s ages 13 through 19 . Ten year adult age dummy variables are included for women in their 30s through 70s. Complexion dummy variables are included for Native-Americans, black, mixed-race, Mexican, and an unspecified complexion group. To account for net cumulative nutrition since birth, US and international nativity dummy variables are included to measure the relationship between BMI and regional conditions at the time of birth. US residence dummy variables are included to account for current conditions facing a woman at the time of measurement. Occupation dummy variables are included to account for how BMIs varied by socioeconomic status, and observation period dummy variables are included to consider how women’s BMI varied overtime.

Table 2’s Model 1 presents least squares BMI estimates for the total sample. Models 2 through 4 present multinomial models in relative risk rates for underweight, overweight, and obese categories relative to the normal category. Model 5 presents least squares estimates for black women born in the US, while Model 6 does the same for US-born white women. 
Table 2, Late $19^{\text {th }}$ and early $20^{\text {th }}$ Century Women's BMIs by Characteristics

\begin{tabular}{|c|c|c|c|c|c|c|}
\hline & Model 1 & Model 2 & Model 3 & Model 4 & Model 5 & Model 6 \\
\hline & $\begin{array}{c}\text { Total } \\
\text { BMI } \\
\text { Sample }\end{array}$ & Underweight & Overweight & Obese & Black & White \\
\hline $\begin{array}{l}\text { Intercept } \\
\text { Height }\end{array}$ & $40.95^{* * *}$ & $8.21^{-5 * * *}$ & $931.19 * * *$ & $11010.60 * * *$ & $42.95 * * *$ & $40.95 * * *$ \\
\hline $\begin{array}{l}\text { Centimeters } \\
\text { Ages }\end{array}$ & $-.116^{* * *}$ & $1.05 * * *$ & $.947 * * *$ & $.922 * * *$ & $-.125 * * *$ & $-.120 * * *$ \\
\hline Preteen & $-5.56 * * *$ & $65.14^{* * *}$ & .305 & $2.58^{-13 * * *}$ & & \\
\hline 13 & $-4.83 * * *$ & 2.64 & $8.66^{-8 * * *}$ & $1.44^{-7 * * *}$ & & \\
\hline 14 & $-3.29 * * *$ & $10.41^{* * *}$ & $.086^{* *}$ & .417 & $-3.28 * * *$ & $-2.64 * * *$ \\
\hline 15 & $-2.72 * * *$ & $5.74 * * *$ & $.275 * *$ & $2.50^{-7} * * *$ & $-2.46 * * *$ & $-3.37 * * *$ \\
\hline 16 & $-1.33 * * *$ & 1.25 & $.461 * * *$ & $.107 * *$ & $-1.31 * * *$ & $-1.57 * *$ \\
\hline 17 & $-1.22 * * *$ & $1.61 *$ & $.401 * * *$ & $.096 * *$ & $-1.45 * * *$ & .111 \\
\hline 18 & $-.731 * * *$ & 1.17 & $.575 * * *$ & $.362 * *$ & $-.478 * *$ & $-.929 * * *$ \\
\hline 19 & $-.565 * * *$ & .696 & $.560 * * *$ & $.470 * *$ & $-.676^{* * *}$ & -.550 \\
\hline $20 s$ & Reference & Reference & Reference & Reference & Reference & Reference \\
\hline $30 \mathrm{~s}$ & $1.27 * * *$ & .863 & $1.48 * * *$ & $2.99 * * *$ & $1.74 * * *$ & $.882 * * *$ \\
\hline $40 \mathrm{~s}$ & $1.71 * * *$ & 1.07 & $1.80 * * *$ & $3.99 * * *$ & $1.09 * * *$ & $2.28 * * *$ \\
\hline $50 \mathrm{~s}$ & $1.61 * * *$ & $1.83 *$ & $2.08 * * *$ & $4.28 * * *$ & $1.13^{* *}$ & $2.54 * * *$ \\
\hline $60 \mathrm{~s}$ & $1.64 * *$ & .530 & $1.26 * * *$ & $5.79 * * *$ & $2.66^{* *}$ & $1.66 * * *$ \\
\hline $70 \mathrm{~s}$ & $4.58 * * *$ & $2.04^{-7} * * *$ & $3.11^{*}$ & $10.77 * *$ & 2.94 & $6.70 * * *$ \\
\hline Ethnicity & & & & & & \\
\hline White & Reference & Reference & Reference & Reference & Reference & Reference \\
\hline $\begin{array}{l}\text { Native } \\
\text { American }\end{array}$ & $1.16^{*}$ & $2.49^{-7} * * *$ & 1.89 & $3.19^{-7} * * *$ & & \\
\hline Black & $.493 * * *$ & $.496 * * *$ & $1.36 * *$ & 1.14 & & \\
\hline Mixed-Race & $.422 * *$ & $.574 * * *$ & $1.33^{* *}$ & 1.21 & & \\
\hline Mexican & -.278 & 1.18 & 1.27 & .753 & & \\
\hline $\begin{array}{l}\text { Uncertain } \\
\text { Complexion } \\
\text { Nativity }\end{array}$ & .606 & 2.40 & .516 & 2.79 & & \\
\hline Northeast & $1.81^{*}$ & 1.33 & 2.40 & 2.62 & 1.06 & 2.30 \\
\hline $\begin{array}{l}\text { Middle } \\
\text { Atlantic }\end{array}$ & .194 & .934 & .884 & 1.21 & .450 & .061 \\
\hline Great Lakes & .337 & 1.05 & 1.30 & 1.06 & .152 & .418 \\
\hline Plains & .179 & 1.36 & 1.00 & 1.26 & .184 & .374 \\
\hline Southeast & -.109 & .977 & 1.09 & .837 & .092 & -.748 \\
\hline Southwest & Reference & Reference & Reference & Reference & Reference & Reference \\
\hline Far West & .023 & $2.91 * *$ & 1.40 & 1.22 & .817 & -.265 \\
\hline British & .006 & .841 & $1.67 *$ & $.219 * *$ & & \\
\hline European & $1.05^{* *}$ & .620 & 1.07 & 1.15 & & \\
\hline Canada & .408 & .540 & .823 & 1.29 & & \\
\hline Latin & -.388 & .455 & $.561 *$ & .656 & & \\
\hline
\end{tabular}




\begin{tabular}{|c|c|c|c|c|c|c|}
\hline $\begin{array}{l}\text { America } \\
\text { Uncertain }\end{array}$ & .521 & $3.52 * *$ & $2.60 * * *$ & 1.55 & & \\
\hline Residence & & & & & & \\
\hline Arizona & .802 & .761 & 2.18 & 1.83 & & \\
\hline Colorado & .094 & .614 & $1.61^{* *}$ & .653 & & \\
\hline Idaho & 1.08 & .932 & .974 & 2.04 & & \\
\hline Illinois & .473 & .785 & 1.13 & $1.66^{*}$ & .318 & .850 \\
\hline Kentucky & .255 & .907 & 1.36 & .874 & .313 & .595 \\
\hline Mississippi & .167 & .460 & 1.49 & $4.02^{-7} * * *$ & .164 & $2.08 *$ \\
\hline Missouri & .382 & .939 & 1.20 & 1.53 & .110 & .927 \\
\hline Montana & .133 & 1.31 & 1.43 & 1.18 & & \\
\hline Nebraska & -.089 & .998 & 1.45 & .617 & -.262 & .494 \\
\hline New Mexico & -.426 & .639 & 1.15 & $3.05^{-7} * * *$ & & \\
\hline Oregon & -.236 & $8.19^{-8 * * *}$ & 1.78 & $2.08^{-7} * * *$ & & \\
\hline Pennsylvania & $.913^{* *}$ & .675 & $1.68 * *$ & 1.99* & .769 & 1.07 \\
\hline Philadelphia & $-1.21 * * *$ & 1.31 & .741 & $.265^{* *}$ & $-1.40 * *$ & -.655 \\
\hline Tennessee & .182 & .794 & 1.03 & 1.06 & -.094 & -.655 \\
\hline Texas & Reference & Reference & Reference & Reference & Reference & Reference \\
\hline Utah & -.462 & $447497.20 * * *$ & 1.45 & .473 & & \\
\hline Washington & .209 & $1.15^{-6 * * *}$ & 6.52 & $8.79^{-8 * * *}$ & & \\
\hline West & & & & & .583 & .728 \\
\hline Occupations & & & & & & \\
\hline Skilled & .314 & $1.77 * *$ & 1.32 & $2.25 * *$ & .080 & .847 \\
\hline Unskilled & .268 & .801 & 1.04 & $2.08 *$ & .229 & .186 \\
\hline Domestic & .237 & 1.13 & 1.14 & $1.74 *$ & .157 & .335 \\
\hline No & Reference & Reference & Reference & Reference & Reference & Reference \\
\hline Occupation & & & & & & \\
\hline Received & & & & & & \\
\hline $1860 \mathrm{~s}$ & $2.05 * *$ & $4.75^{-7} * * *$ & 2.22 & $6.48 * *$ & $2.24 * *$ & $4.31 * * *$ \\
\hline $1870 \mathrm{~s}$ & $.744 * * *$ & .810 & 1.27 & $2.39 * * *$ & $.589 * *$ & .464 \\
\hline 1880s & .180 & .778 & 1.09 & .882 & .201 & .202 \\
\hline 1890s & $-.303 *$ & 1.14 & .937 & .934 & $-.522 * * *$ & .433 \\
\hline 1900s & Reference & Reference & Reference & Reference & Reference & Reference \\
\hline 1910s & $.653^{* * *}$ & .947 & $1.28 * *$ & $2.49 * * *$ & $.647 * * *$ & .343 \\
\hline 1920s & .390 & .700 & .985 & $2.36 * * *$ & -.060 & .539 \\
\hline 1930s & .304 & 1.33 & .793 & $4.09 *$ & -1.31 & .009 \\
\hline $\mathrm{N}$ & 4,766 & 4,766 & 4,766 & 4,766 & 2,841 & 1,285 \\
\hline $\mathrm{R}^{2}$ & .1373 & .0961 & .0961 & .0961 & .1569 & .1175 \\
\hline
\end{tabular}

Source: See Table 1.

Note: *** significant at .01; ${ }^{* *}$ significant at .05; * significant at .10 . 
Three paths of inquiry are considered when evaluating women's late $19^{\text {th }}$ and early $20^{\text {th }}$ century BMIs and weight classification. First, $19^{\text {th }}$ century male statures varied by complexion (Steckel, 1979; Carson, 2008a), and fairer complexioned males were taller than their darker complexioned counterparts, a pattern known as the 'mulatto advantage' (Bodenhorn, 1999). This stature by complexion relationship has been attributed to $19^{\text {th }}$ century social preferences that favored individuals with fairer to darker complexions (Bodenhorn, 1999, pp. 994-995;

Bodenhorn, 2001). However, if this stature advantage was due to social preferences, white women should have had greater BMIs than mixed-race women, who should have had greater BMIs than darker complexioned black women. In fact, the opposite is true (Table 3), and after accounting for characteristics, darker complexioned black women had greater BMI values than fairer complexioned white women, which indicates that social preferences favoring fairer complexioned blacks is not likely the primary explanation for mixed-race and having greater BMIs or whites being taller than darker complexioned blacks (Carson, 2008; Carson, 2009; Carson, 2015).

On the other hand, multiple explanations account for why black women had greater BMIs than white women. Black women may have had greater BMIs because individuals with darker complexions have more protein in muscle tissue, and muscle is heavier than fat (Barondess et al. 1997; Wagner and Heyward, 2000). Nineteenth century African-American households also devoted a greater share of their incomes to food than whites, and although black household incomes were lower than whites, black inter-family calorie and nutrition allocation may have allowed black women to gain more weight than whites (Higgs, 1977, p. 105; Bodenhorn, 2015, pp. 144-166). To the degree that female BMIs represent in-utero conditions of their children, greater African-American women BMIs indicate that in-utero conditions may not have been an 
impediment to early black childhood survival compared to white children and that it was conditions after birth that were responsible for high black childhood mortality rates. In sum, women with darker complexions had greater BMIs than women with fairer complexions, and black in-utero conditions may be an unlikely explanation for later life health for the children of darker complexioned women.

Figure 3, Late $19^{\text {th }}$ and Early $20^{\text {th }}$ Century BMIs by Observation Period

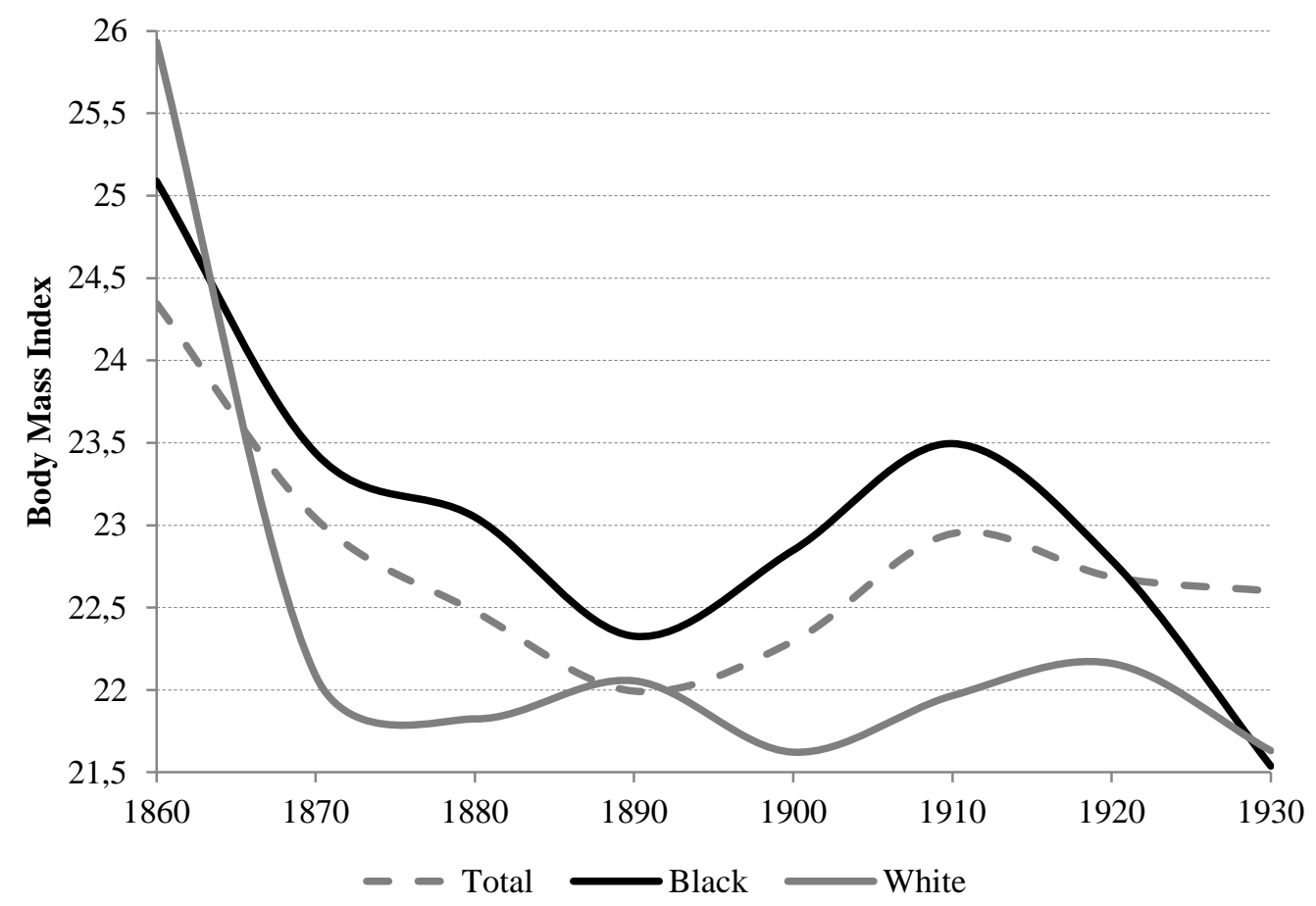

Source: See Table 1 and 3.

Second, women’s BMIs varied over time, and between 1860 and 1930, the BMIs of African-American women decreased by 14.2 percent, while white women's BMIs decreased by 17 percent. Komlos (1987) and Carson (2008b) show that nutrition decreased with the separation of food consumption from food production, which increased the relative price of 
nutrition. Much of this decrease may have been associated with agricultural commercialization and industrialization. In 1800, most US agriculture was produced on single family farms that produced food and dairy products for household consumption; little surplus was left over for market transactions. During this pre-refrigeration period, the integrity of animal proteins and dairy products were also degraded when the distance between agricultural production and household consumption increased (Komlos, 1987; Craig et al. 2008; Carson, 2008, pp. 367-368). Moreover, during the mid- $19^{\text {th }}$ century, storage techniques to preserve dairy products used tin cans to store fluid milk, which compromised dairy quality when it was transported from rural to urban locations (Fletcher, 1955, p. 165; Cochrane, 1979, pp. 76-77). By 1910, much of US agriculture transformed into a highly commercial industry, which separated food consumption from production, and increased the relative price of nutrition. This separation of agricultural consumption from production increased the relative cost of net nutrition and put stress on women’s current net nutrition (Kiple and King, 1981, p. 83; Komlos, 1987; Carson, 2008b). There was a mild increase in black women’s BMIs around 1900; white women experienced a smaller, slight increase around 1910, yet the overall trend in women’s BMIs decreased. Subsequently, unlike modern samples, throughout the late $19^{\text {th }}$ and early $20^{\text {th }}$ centuries, there was no trend toward female obesity, and like men, women's BMIs decreased throughout the late $19^{\text {th }}$ and early $20^{\text {th }}$ centuries (Carson, 2008a; Carson, 2009a; Carson, 2016).

Third, there was little BMI variation within the US by residence, and women in rural Pennsylvania had greater BMIs and were more likely to be overweight and obese than women elsewhere within the US. Residents in rural Pennsylvania lived in the dairy producing counties of Bucks, Chester, and Lancaster counties (Carson, 2008b, pp. 367-368), indicating that women in dairy producing regions faced lower relative food prices in close proximity to dairy 
production. Alternatively, women in urban Philadelphia faced relatively high net nutrition prices and had lower BMIs than women elsewhere within the US. Women in the South were tall and had larger physical dimensions to distribute weight, which was associated with low BMIs (Sorkin et al. 1999a; Sorkin et al. 1999b; Carson, 2011; Carson, 2013). Within the South, white women in Mississippi were the only Southern women to have significantly greater BMIs than women observed elsewhere within the US, and Southern whites had greater access to diverse diets that had more calories, which included corn, pork, beef, and Irish potatoes (Hilliard, 1972). Patterns for non-US born women in the US are also noteworthy, and after accounting for shorter statures, British women had BMIs comparable to Southern US women and may have been more likely to be overweight but not obese. Women with other international nativities were not significantly different from Southern US women.

Other patterns are consistent with expectations. BMIs varied by age, and after controlling for characteristics, white women's BMIs increased with age more than black women, indicating that young white women had greater access to net nutrition during their youth. Although maternal social position is related to off-spring birth size, women's occupations were mostly not related to BMIs. In sum, there were complex interactions between the late $19^{\text {th }}$ and early $20^{\text {th }}$ century women's net nutritional conditions, and after controlling for observable characteristics, black women had higher BMIs than white women.

\section{Explaining the Difference between Late $19^{\text {th }}$ and Early $20^{\text {th }}$ Century Women's BMIs}

To more fully account for US black and white women’s BMI differential and to assess the relative magnitudes of characteristic relationships, a black-white female Blinder-Oaxaca 
decomposition is constructed (Oaxaca, 1973). A Blinder-Oaxaca decomposition partitions the difference between samples that accrue to returns to characteristics and differences that accrue to average characteristics. Let $\mathrm{BMI}_{\mathrm{b}}$ and $\mathrm{BMI}_{\mathrm{w}}$ represent the body mass of black and white women, respectively. $\theta_{0 b}$ and $\theta_{0 w}$ are the autonomous body mass components that accrue to black and white women. $\theta_{1 b}$ and $\theta_{1 w}$ are the BMI returns associated with black and white characteristics, such as age and occupation. Characteristic matrices $\bar{X}_{b}$ and $\bar{X}_{w}$ are average characteristic matrices, and average black women’s BMI are assumed to be the base structure.

$$
\begin{aligned}
& \text { Black BMI function: } \quad \mathrm{BMI}_{\mathrm{b}}=\theta_{0 b}+\theta_{1 b} \bar{X}_{b} \\
& \text { White BMI function: } \mathrm{BMI}_{\mathrm{w}}=\theta_{0 w}+\theta_{1 w} \bar{X}_{w}
\end{aligned}
$$

The black and white BMI gap is.

$$
\Delta B M I=B M I_{b}-B M I_{w}=\theta_{0 b}+\theta_{1 b} \bar{X}_{b}-\theta_{0 w}-\theta_{1 w} \bar{X}_{w}
$$

Adding and subtracting $\theta_{\mathrm{b}} \mathrm{X}_{\mathrm{w}}$ to the right hand side of the equation and collecting like terms is

$$
\Delta B M I=B M I_{b}-B M I_{w}=\left(\theta_{0 b}-\theta_{0 w}\right)+\left(\theta_{1 b}-\theta_{1 w}\right) \bar{X}_{b}+\theta_{w}\left(\bar{X}_{b}-\bar{X}_{w}\right)
$$

The first right-hand side element, $\left(\theta_{0 b}-\theta_{0 w}\right)$, is the BMI differential due to nonidentifiable sources, such as greater muscle mass and bone mineral density that favored black women (Barondess et al. 1997, Wagner and Heyward, 2000). Non-identifiable sources in the intercept also include being born a slave or not well nourished in-utero and during early childhood (Trussell and Steckel, 1992, pp. 444-449). The second right hand-side element, $\left(\theta_{1 b}-\theta_{1 w}\right) \bar{X}_{b}$, is the component of the BMI differential due to BMI return differences associated with characteristics. The difference is positive if black women’s BMI returns associated with characteristics is greater than for white women and negative if white women's BMI returns was 
greater than for black women. The third right-hand side element, $\theta_{w}\left(\bar{X}_{b}-\bar{X}_{w}\right)$, is the part of the BMI differential due to average characteristics. The difference is positive if average characteristics were greater than white women and negative when white average characteristics are greater than black women.

Table 3, Late $19^{\text {th }}$ and early $20^{\text {th }}$ Century Black-White Women's BMI Decomposition

\begin{tabular}{l|cccc}
\hline Levels & $\left(\beta_{\mathrm{b}}-\beta_{\mathrm{w}}\right) \mathrm{X}_{\mathrm{b}}$ & $\left(\mathrm{X}_{\mathrm{b}}-\mathrm{X}_{\mathrm{w}}\right) \beta_{\mathrm{w}}$ & $\left(\beta_{\mathrm{b}}-\beta_{\mathrm{w}}\right) \mathrm{X}_{\mathrm{w}}$ & $\left(\mathrm{X}_{\mathrm{b}}-\mathrm{X}_{\mathrm{w}}\right) \beta_{\mathrm{b}}$ \\
\hline Levels & $\begin{array}{c}\text { Returns to } \\
\text { Characteristics }\end{array}$ & $\begin{array}{c}\text { Average } \\
\text { Characteristics }\end{array}$ & $\begin{array}{c}\text { Returns to } \\
\text { Characteristics }\end{array}$ & $\begin{array}{c}\text { Average } \\
\text { Characteristics }\end{array}$ \\
Sum & 1.29 & -1.21 & .789 & -.716 \\
Total & & .073 & & .073 \\
Proportions & & & 27.46 & \\
Intercept & 27.46 & & -11.10 & 1.27 \\
Height & -11.05 & 1.22 & .189 & -7.35 \\
Ages & .141 & -7.30 & 3.28 & -1.96 \\
Nativity & 5.65 & -4.33 & -4.47 & -1.50 \\
Residence & -.678 & -5.29 & -2.70 & -.041 \\
Occupations & -1.82 & -.920 & -1.83 & -.257 \\
Observation & -1.97 & -.117 & & -9.83 \\
Period & & & 10.83 & 1 \\
Sum & 17.74 & -16.74 & & \\
Total & & 1 & & \\
\hline Source: See Tam & & & & \\
\hline
\end{tabular}

Source: See Tables 1 and 3.

Using coefficients from women’s BMI regressions Table 3, Models 5 and 6 indicate that in both levels and proportions, black compared to white women had considerable advantages from non-identifiable sources in the intercept, which includes greater percent protein in muscle tissue. The greatest share of the black-white difference in proportions is due to how white BMIs increased with stature relative to black women, indicating that white women's cumulative net nutritional advantage had lasting effects. White to black women’s BMI advantage also extended 
to greater BMI returns with residence, occupations, and observation period. The BMI gap was also explained by differences in average characteristics, and white women had greater returns associated with average age, nativity, residence, occupations, and observation period.

Alternatively, black women had greater BMI advantages associated with BMI returns to nativity and average heights. In sum, after controlling for characteristics, black woman historically had greater average BMIs than white women, which had implications for conditions during economic development, race relations within the $19^{\text {th }}$ century US, and how resources were located during economic development.

\section{Conclusion}

The health and current net nutrition of women during early urbanization and industrialization indicates much about how their own health and the health of their off-spring vary with economic development (Osmania and Sen, 2003). This study demonstrates that late $19^{\text {th }}$ and early $20^{\text {th }}$ century black women had greater BMI values than mixed race and white women. Between 1860 and 1930, black women’s BMIs decreased by 14 percent, while white women’s BMIs decreased by 17 percent, indicating that decreasing women’s BMIs reflect deteriorating net nutritional conditions for themselves and the fetal conditions for children born in the late $19^{\text {th }}$ and early $20^{\text {th }}$ centuries. The separation of food production from food production increased the relative price of food, and young women's BMIs decreased throughout the late $19^{\text {th }}$ and early $20^{\text {th }}$ centuries as agricultural and labor markets industrialized. This decrease in $19^{\text {th }}$ century women’s BMIs over time may have had inter-generational consequences. If working class women had poor current net nutrition during pregnancy, their children may have been at greater risk of heart disease, stroke, and diabetes in later-life (Yan, 2015; Richards et al, 2001, p.

201; Rode et al., 2007). Children born to mothers with poor nutrition are also more likely to 
have low birth weights, higher adult plasma glucose, high insulin concentrations, and type-2 diabetes (Yan, 2015; Ravelli et al., 1999; Ben-Shiromu and Smith, 1991; Kramer and Jospeh, 1996). Moreover, poor in-utero and early life conditions also reduces cognitive function during children’s formative years, which impairs child later-life economic outcomes (Sørensen et al, 1997, p. 402; Richards et al. 2007; Hack et al. 2002, pp. 149 and 151; Case and Paxson, 2008a; Case and Paxson, 2008b). Women from the Southwest were taller and had lower BMIs than women located elsewhere within the US. Women from Continental Europe had greater BMIs, which is due, in part, to women reaching shorter statures who had low cumulative net nutrition that began during their European childhood, but their net nutrition improved upon migration to the US. Subsequently, during the late $19^{\text {th }}$ and early $20^{\text {th }}$ century, low and decreasing net nutrition for women in lower socioeconomic groups may have persisted in their off-spring into the middle of the $20^{\text {th }}$ century with cognitive function, insulin resistance, and adult-onset diabetes. 


\section{References}

Abrams, Barbara, Sarah Altman, and Kate Pickett. (2000). "Pregnancy Weight Gains: Still Controversial.” American Journal of Clinical Nutrition 7 (suppl)., pp. 1233s-1241s).

Antonov, A. N. (1947). “Children Born during the Seige at Leningrad in 1942.” Journal of Pediatrics 30, pp. 250-259.

Barker, David (1992). Fetal and Infant Origins of Adult Disease. London. British Medical Journal.

Barker, David (1997). “Maternal Nutrition, Fetal Nutrition, and Disease in Later Life.” Nutrition, 13, 9, pp. 807-813.

Barker, David. (1998). “In Utero Programming of Chronic Disease.” Clinical Science, 95, pp. 111-128.

Barondess, D. A., D. A. Nelson, and S. E. Schlaen, 1997. Whole body bone, fat and lean mass in black and white men. Journal of Bone and Mineral Research 12: 967-971.

Belue, Rhonda, Lori Ann Francis, and Brenda Colaco. 2009. “Mental Health Problems and Overweight in Nationally Representative Sample of Adolescents: Effects of Race and Ethnicity.” Pediatrics 123, 697-702.

Ben-Shiromu, Y., G. D. Smith. 1991. “Deprivation in Infancy or in Adult Life: Which is More Important for Mortality Risk?” Lancet 337, pp. 530-534.

Björntorp, Tone, Randi Marie Selmer, and Aage Tverdal. (2003). “Height and Body Mass Index to Total Mortality.” Epidemiology. 14, pp. 293-299.

Bodenhorn, H. 1999. A troublesome caste: height and nutrition of antebellum Virginia's rural free blacks. Journal of Economic History 59: 972-996.

Bodernhorn, H. (2015). The Color Factor: The Economics of African-American Well Beingt in 
the Nineteenth Century South. Oxford: Oxford University Press.

Bodenhorn, Howard, Carolyn Moehling, and Gregory Price (2012). “Short-Criminals: Stature and Crime in Early America.” Journal of Law and Economics 55, pp. 319-419.

Brownson, Ross C., Tegan Boehmer, and Douglas Luke (2005). “Declining Rates of Physical Activity in the United States: What are the Contributors?” Annual Review of Public Health 26, pp. 421-443.

Burkhauser, R. \& Cawley, J. (2008). “Beyond BMI: The Value of More Accurate Measures of Fatness and Obesity in Social Science Research.” Economics and Human Biology, 27, pp. 519-529.

Burnette, Joyce (2013). “The Changing Economic Roles of Women.” In: Robert Whaples and Randall Parker (Eds.). Routledge Handbook of Modern Economic History. Routledge Press: New York. pp. 306-315.

Calle, Eugenia, Thun, M. Petrilli, J. Rodriguiez, C., and Meath, C. (1999). “Body Mass Index and Mortality in a Prospective Cohort of US Adults.” New England Journal of Medicine 34, pp. 1097-1104.

Carmalt, Julie, John Cawley, Kara Joyner, Jeffrey Sobel (2008). “Body Weight and Matching with a Physically Attractive Romantic Partner.” Journal of Marriage and the Family. 70, pp. 1287-1296.

Carson, Scott Alan. (2008a) “The Effect of Geography and Vitamin D on African-American Stature in the $19^{\text {th }}$ Century: Evidence from Prison Records,” Journal of Economic History, 68(3), pp. 812-830.

Carson, Scott Alan. (2008b) “Health during Industrialization: Evidence from the $19^{\text {th }}$ Century Pennsylvania State Prison System,” Social Science History. Volume 32(3). Pp. 347-372. 
Carson, Scott Alan. (2009a) "Racial Differences in Body-Mass Indices of Men Imprisoned in $19^{\text {th }}$ Century Texas” Economics and Human Biology 7, pp. 121-127.

Carson, Scott Alan, (2009b) “Geography, Insolation and Vitamin D in 19th Century US AfricanAmerican and White Statures,” 46(1), Explorations in Economic History. pp. 149-159.

Carson, Scott A. (2011). "Height of Female Americans in the $19^{\text {th }}$ Century and the Antebellum Puzzle.” Economics and Human Biology, 9(2), 157-164.

Carson, Scott Alan. (2012a), “Nineteenth Century Race, Body Mass, and Industrialization: Evidence from American Prisons,” Journal of Interdisciplinary History 42. Pp. 371-391. Carson, Scott Alan. (2013). “Socioeconomic Effects on the Stature of Nineteenth Century US Women.” Feminist Economics 19, pp. 122-143.

Carson, Scott Alan (2015). “Biology, Complexion, and Socioeconomic Status: Accounting for $19^{\text {th }}$ Century Body Mass Index by Race.” Australian Economic History. 55, 3, pp. 238255.

Carson, Scott Alan (2016). "Body Mass Index through Time: Explanations, Evidence, and Future Directions.” In John Komlos and Inas Rashad Kelley (eds.) The Handbook of Economics and Human Biology. Oxford: Oxford University Press.

Case, Ann and Christina Paxson. (2008a). "Height, Health, and Cognitive Function at Older Ages.” American Economic Review 98, pp. 463-467.

Case, Ann and Christina Paxson. (2008b). "Stature and Status: Height, Ability and Labor Market Outcomes.” Journal of Political Economy 116, pp. 499-532.

Church, Timothy, Diane Thomas, Catrine Tudor-Locke, Peter T. Katzmarzyk, Conrad P. 
Earnest, Ruben Q. Rodarte, Corby K. Martin, Steven N. Blair, and Claude Bouchard. (2011). “Trends over Five Decades in U.S. Occupation-Related Physical Activity and Their Associations with Obesity.” PlosOne 6, 5.

Cochrane, W. (1979). The Development of American Agriculture. Minneapolis: University of Minnesota Press.

Cohen, Raymond. (2009). Mass Migration Under Sail: European Immigration to the Antebellum United States. Cambridge: Cambridge University Press.

Doherity, D. A., E. F. Magann, J, Francis, J.C. Morrison, J. P. and Newham (2006). “PrePregnancy Body Mass Index and Pregnancy Outcomes.” Gynecology and Obstetrics 95, pp. 242-247.

Dunbar, Robin I. (2013). “Obesity: An Evolutionary Perspective.” In Avner Offer, Rachel Pechey, and Stanley Ulijaszek (Eds.). Insecurity, Inequality, \& Obesity. Oxford University Press, Oxford. Pp. 55-68.

Ehrenberg, Hugh, Leroy Dierker, Cynthia Milluzzi, and Brian Mercer (2013). “Low Maternal Weight, Failure to Thrice in Pregnancy, and Adverse Pregnancy Outcomes.” American Journal of Obstetrics and Gynecology 189, 6, pp. 1726-1730.

Ellias, Merrill, Penelope Ellias, Lisa Sullivan, Philip Wolf, an Ralph D’ Agostro (2003). “Lower Cognitive Function in the Presence of Obesity and Hypertension: The Framingham Heath Study.” International Journal of Obesity 27, pp. 260-268.

Ellias, Merrill, Penelope Ellias, Lisa Sullivan, Philip Wolf, and Ralph D’Agostro (2005). “Obesity, Diabetes, and Cognative Deficit: The Framingham Heart Study.” Neurology of Aging 26s, s11-s16.

Flegal, Katherine, Margaret Carroll, Cynthia Ogden, Lester Curtin (2010). “Prevalence and 
Trends in Obesity among US Adults, 1999- 2008.” Journal of the American Medical Association 303(3), pp. 235-241.

Fletcher, Steven Whitcomb (1955) Pennsylvania Agriculture and Country Like, 1840-1940. Harrisburg, PA: Pennsylvania Historical and Museum Commission.

Fogel, R.W., 1994. Economic Growth, Population Theory and Physiology: The Bearing of Long-Term Processes on the Making of Economic Policy. American Economic Review 84, 369-395.

Fogel, Robert William. (2004). The Escape from Hunger and Premature Death, 1700-2100: Europe, America, and the Third World. Cambridge University Press: Cambridge. Garrow. G. S., Webster, J. D. (1985). “Quetlelete’s Index (W/H²) as a Measure for Fatness.” International Journal of Obesity Related Metabolic Disorders, 9, pp. 147-153.

Ge, Xiaojia, Glen Elder, Mark Regneruss and Christine Cox. 2001. "Pubertal Transitions, Perceptions of Being Overweight, and Adolescents Psychological Maladjustment: Gender and Ethnic Differences.” Social Psychology Quarterly 64, 363-375.

Goldin, Claudia (1990). “Understanding the Gender Gap: An Economic History of American Women.” New York: Oxford University Press.

Goldin, Claudia and Kenneth Sokoloff (1982). "Women, Children, and Industrialization in the Early Republic: Evidence from the Manufacturing Censuses.” Journal of Economic History 42, pp. 741-774.

Granberg, Ellen. (2011). “Depression and Obesity.” In John Cawley’s The Oxford Handbook of the Social Science of Obesity. Oxford: Oxford University Press. pp.. 329-349.

Guth, Eve. (2014). "Healthy Weight Loss.” Journal of the American Medical Association. 312, 9. pp. 974. 
Hack, Maureen, Daniel Flannery, Mark Schluchter, Lydia Carter, Elaine Burawski and Nancy (2002). “Outcomes in Young Adulthood for Very-Low-Birth-Weight Infants.” New England Journal of Medicine 346(3), pp. 149-156.

Herbert, P., Richards-Edwards, J., Manson, J.A., Ridker, P., Cook, N., O’Conner, G., Buring, J., and Hennekens, C. (1993) Height and incidence of cardiovascular disease in male physicians. Circulation 88, p. 1437-1443.

Higgs, Robert (1977). Competition and Coercion: Blacks and the American Economiy, 18651914. Chicago: University of Chicago Press.

Hilliard, Samuel B. Hog, Meat and Hoecake: Food Supply in the Old South, 18401860. Carbondale, IL: Southern Illinois University Press. 1972.

Hirschi, Travis and Michaeal Gottfredson. (1983). “Age and Explanation of Crime.” American Journal of Sociology 89(3), pp. 552-584.

Jee, H., Jee, J., Sull, J., Park, J., Lee, S. Y., Ohrr, H.,Guallar, E., and Samet, J. (2006). “Body Mass Index and Mortality in Korean Men and Women.” New England Journal of Medicine 355, pp. 779-787.

Kiple, Kennth and Virginia King, Another Dimension to the Black Diaspora: Diet, Disease and Racism. Cambridge: Cambridge University Press. 1981.

Koch, D. 2011. Waaler revisited: the anthropometrics of mortality. Economics and Human Biology 9: 106-17.

Komlos, J., 1987, The Height and Weight of West Point Cadets: Dietary Change in Antebellum America. Journal of Economic History 47, 897-927.

Komlos, John and Mark Brabec. (2010). "The Trend of Mean BMI Values of US Adults, Birth Cohorts 1882-1986 Indicates that the Obesity Epidemic Began Earlier than Hitherto 
Thought.” American Journal of Human Biology 22, pp. 631-638.

Kramer, M.S. and K.S. Jospeh. 1996. "Enigma of Fetal Infant Origins Hypothesis.” Lancet 348, p. 1254.

Kuhn, Charles (1992). “An Agency Approach to Slave Punishments and Rewards.” In Without Consent or Contract: Conditions of Slave Life and the Transition to Freedom, edited by R. W. Fogel and S. L. Engerman, 551-568, New York: Norton.

Leiberman, Leslie Su. 2000. “Obesity.” In: Kenneth Kiple and Kriemchild Coneè Ornelas. The Cambridge World History of Food. Cambridge University Press: Cambridge. Pp. 1062-

Meyer, H.E., Sogaard, A. J. Tverdel, A., Selmer, R. M. (2002). “Body Mass Index and Mortality: the Influence of Physical Activity and Smoking.” Medicine and Science in Sports and Medicine 34, pp. 1065-1070.

Monson, JoAnn, Graham Colditz, Meir Stampfer, Walter Willett, Bernard Rosner, Richard Monson, Frank Speizer, and Charles Hennekens. (1990). “A Prospective Study of Obesity and Risk of Coronary Heart Disease in Women.” New England Journal of Medicine 332, 13, pp. 882-889.

Monson, JoAnn, Eric Primm, Meir Stampfuer, Graham Colditz, Walter Willett, Adrezej Krolewski, Bernard Posner, Charles Hennekens, and Frank Speizer. (1991). "Physical Activity and Incidence of non-Insulin-Dependent Diabetes Mellitus in Women.” Lancet 338, pp. 774-778.

Must, Aviva and Whitney Evans. (2011). “The Epidemiology of Obesity.” In Cawley, John (Ed.). The Oxford Handbook of the Social Science of Obesity. Oxford University Press: Oxford, pp. 9-34.

Needham, Belinda and Robert Crosnoe. 2005. "Overweight Status and Depressive Symptoms 
during Adolescence.” Journal of Adolescent Health, 36, 48-55.

Oaxaca R. L. (1973) Male female wage differentials in urban labor markets. International Economic Review 14, 3: 693-709.

Ogden, Cynthia, Margeret Carroll, Lester Curtin, Margaret McDowell, Carolyn Tabak, Katherine Flegal (2006). "Prevalence of Overweight and Obesity in the United States, 1999-2004.” Journal of the American Medical Association 295(13), pp. 235-241.

Osmond, Clive and David Barker. (2000). "Fetal Infant and Childhood Growth are Predictors of Coronary Heart Disease, Diabetes, and Hypertention in Adult Men and Women.” Environmental Health Perspective 108, 3, pp. 545-553.

Osmani, Siddiq and Amartya Sen (2003). “The Hidden Penalities of Gender Inequality: Fetal Origins of Ill-Health.” Economics \& Human Biology 1, pp. 105-121.

Ravelli, A.C.J., J.H.P. van der Meulen, R.P.J Michels, C. Osmond, D.J.P. Barker, C.N. Hales, O.P. Bleker. 1996. "Glucose Tolerance in Adults After Parental Exposure to Famine.” Lancet 351, pp. 173-177.

Richards, Marcus, Rebecca Hardy, Diane Kuh, Michael Wadsworth. (2001). "Birth Weight and Cognitive Function in the British 1946 Birth Cohort: Longitudinal Population.” British Medical Journal 322, pp. 199-203.

Risnes, Kari, Lars Vatten, Jennifer Baker, Karen Jameson, Ulla Sovio, Eero Kajantie, Merete Osler, Ruth Morley, Markus Jokela, Rebecca Painter, Valter Sundh, Geir Jacobsen, Johan Eriksson, Thorkild Sørensen, and Michael Bracken. (2011). “Birthweight and Mortality in Adulthood: a Systematic Review and Meta-Analysis.” International Journal of Epidmeology pp. 1-15.

Rode, Line, Hannah Hegaard, Hanne Kjargaard, Lars Moller, Ann Taber, Bent Otteson (2007). 
“Association between Material Weight Gain and Birth Weight.” Obstetrics \& Gynecology 109, 6, pp. 1309-1315.

Rosmund, R. and P. Pjürnturp (1999). "Psychosocial and Socio-economic Factors in Women and their Relationship to Obesity and Regional Body Fat Distribution.” International Journal of Obesity 23, pp. 138-145.

Siega-Riz, Anna Maria, Anna Maria Siega-Riz, and Barbara Laraia (2006). “The Implications of Maternal Overweight and Obesity on the Course of Pregnancy and Birth Outcomes. “ Maternal Child Health Journal 10. pp. s153-s156.

Sørensen, Henrik, Svend Sabroe, Jørn Olsen, Kenneth Rothman, Matthew Gillman, and Peer Fischer. (1997). “Birth Weight and Cognitive Function in Young Adult Life: Historical Cohort Study.” British Medical Journal 315, pp. 401-403.

Sorkin, John, Denis Muller, and Reubin Andres. 1999a. "Longitudinal Change in the Heights of Men and Women: Consequential Effects on Body Mass Index.” Epidemiologic Reviews. 21, 2, pp. 247-260.

Sorkin, John, Denis Muller, and Reubin Andres. 1999b. “Longitudinal Change in Height of Men and Women: Implicaitons for Interpretation of the Body Mass Index, The Baltimore Longitudinal Study of Aging.” American Journal of Epidemiology 150, 9, pp. 969-977.

Steckel, R. H. 1979. Slave height profiles from coastwise manifests. Explorations in Economic History 16: 363-380.

Steckel, Richard (1986a). “A Peculiar Population: The Nutrition, Health, and Mortality of American Slaves Childhood to Maturity.” Journal of Economic History 46, pp. 721-741. Steckel, Richard (1986b). “A Dreadful Childhood: The Excess Mortality of American Slaves.” Social Science History 10, pp. 427-465. 
Steffensmeier, Darrell, and Emilie Allan (1996). "Gender and Crime: Toward a Gendered Theory of Female Offending.” Annual Review of Sociology 22, pp. 459-487.

Stein, Z. (1975). Famine and Human Development: the Dutch Hunger Winter of 1944-1945. New York: Oxford University Press.

Stevens, June, Jianwen Cai, Elsie Pamuk, David Williamson, Michael Thun, and Joy Woods. "The Effects of Age on the Association Between Body-Mass Index and Mortality,” New England Journal of Medicine, 338 (1), 1998, pp. 1-7.

Sunder, Marco (2011). "Height of Female Americans in the $19^{\text {th }}$ Century and the Antebellum Puzzle.” Economics and Human Biology. 9(2). pp. 165-171.

Sundstrum, William. (2013). “African-Americans since Emancipation.” In: Robert Whaples and Randall Parker (Eds.). Routledge Handbook of Modern Economic History. Routledge Press: New York. pp. 316-340.

Symons, Donald (1995). "Beauty is in the Adaptation of the Beholder: The Evolutionary Psychology of Human Female Attractiveness.” In: Abramson, Paul and Steven Pinkerton (eds.). Sexual Nature, Sexual Culture. Chicago: University of Chicago Press. pp. 80-118.

Tovée, M. J., S. Reinhardt, J. L. Emory, P. L. Comelissen (1998). “Optimum Body Mass and Maximum Sexual Attractiveness.” The Lancet 352, p. 548.

Trussell, James and Richard Steckel (1992). "The Age of Slaves at Menarche and Their First Birth.” In: Robert W. Fogel and Stanley L. Engerman. (Eds.). Without Consent or Contract: Conditions of Slave Life and the Transition to Freedom, Technical Papers, V. 2, Norton Publishers: New York. pp. 435-454.

Waaler, Hans. 1984. “Height, Weight, and Mortality: The Norwegian Experience.” Acta 
Medica Scandinavica, Suppliment 679.

Wagner, D. R. and V. H.Heyward, 2000. Measures of composition in blacks and whites: a comparative review. American Journal of Clinical Nutrition 71: 1392-1402.

Walker, Donald (1988). Penology for Profit: A History of the Texas Prison System, 1967-1912. College Station: Texas A \& M University Press.

Wing, Rena and Suzanne Phelan (2005). “Long-Term Weight Loss Maintenance.” American Journal of Clinical Nutrition. 82 pp. 222s-225s.

World Health Organization (1985). "Physical Status: the Use and Interpretation Anthropometry.” Report of a World Health Organization Committee. World Health Organization Technical Rep. Ser., pp. 1-452.

Yan, Jin (2015). "Maternal Pre-Pregnancy BMI, Gestational Weight Gain, and Infant Birth Weight: A Within Family Anaysis in the United States.” Economics and Human Biology 18, pp. 1-12.

Zimmerman, Michael, Carolyn Gubeli, Claudia Putener, and Luciano Muliner. (2004). "Detection of Overweight and Obesity in a National Sample of 6-12 year-old Swiss Children: Accuracy and Validity of Reference Values for Body Mass Index from US Centers for Disease Control and Prevention and International Obesity and Prevention.” Prevention and International Obesity.

Zimran, Ariell (2015). "Does Sample-Selection Bias Explain the Industrialization Puzzle? Evidence from Military Enlistment in the Nineteenth-Century United States” http://aez.econ.northwestern.edu/zimran_height_selection.pdf 